ЕКОНОМІЧНА ТЕОРІЯ ТА ІСТОРІЯ ЕКОНОМІЧНОЇ ДУМКИ

UDC $330.341 .2(477)$

DOI: https://doi.org/10.32782/2520-2200/2020-1-1

\author{
Nikiforov Petro \\ Yuriy Fedkovych Chernivtsi National University \\ Pochenchuk Galyna \\ Yuriy Fedkovych Chernivtsi National University \\ Babukh llona \\ Yuriy Fedkovych Chernivtsi National University
}

Нікіфоров П.О.

доктор економічних наук, професор,

Чернівецький національний університет імені Юрія Федьковича

Поченчук Г.М.

доктор економічних наук, доцент,

Чернівецький національний університет імені Юрія Федьковича

Бабух І.Б.

кандидат економічних наук, доцент,

Чернівецький національний університет імені Юрія Федьковича

\title{
PRIORITIES IN INSTITUTIONAL TRANSFORMATION OF ECONOMY OF MODERN UKRAINE
}

\section{ПРІОРИТЕТИ В ІНСТИТУЦІОНАЛЬНИХ ТРАНСФОРМАЦІЯХ ЕКОНОМІКИ СУЧАСНОÏ УКРАЇНИ}

The existing economic model in Ukraine by its basic properties does not require innovation, it does not involve investment in human capital. In today's context, the restructuring of the economic model of Ukraine is urgently needed, which should be refocused on stimulating and financially supporting large financial and industrial capital for the development of competition, optimizing the regulatory functions of the state and its role in the national reproduction process, significant activation of small and medium-sized businesses. In terms of institutional transformation, the strategic task of the current stage of reforming the national economy is to build an effective system of governance at all levels, to identify new roles at different levels of government, which implies the optimal combination of decentralization and the coordinating, stimulating role of the center.

Keywords: institute, institutional transformation, institutional reform, model of economy, legal state, civil society, governing system, institutional management.

Існуюча в Україні економічна модель за своїми базовими властивостями не потребує інновацій, не передбачає інвестицій у людський капітал. В Україні не відбулося чіткого розмежування між економічними інтересами приватного капіталу, бюрократичною природою держави та суспільними інтересами. В сучасних умовах вкрай необхідна перебудова економічної моделі України, яка повинна бути переорієнтована зі стимулювання та фрінансової підтримки великого фрінансовопромислового капіталу на розвиток конкуренції, оптимізацію регулятивних функцій держави та її ролі в національному процесі відтворення, значну активізацію малого і середнього бізнесу. Звідси, в плані інституціональних трансформацій стратегічним завданням сучасного етапу реформування національної економіки є побудова ефективної системи управління на всіх рівнях, визначення нових ролей різних рівнів державного управління, яке передбачає оптимальне поєднання децентралізації та координуючої, стимулюючої ролі центру. Це зумовлює необхідність запровадження принципів гнучкого публічного інституціонального управління при розробці та реалізації програм економічного розвитку та інституціонального реформування з метою забезпечення адаптаційних можливостей реагувати на виклики мінливого середовища, а також врахування сучасних тенденцій цифровізації. Зазначені тенденції передбачають зменшення центральної ролі держави в особі уряду внаслідок зростання конкуренції, перерозподілу і децентралізації влади, зміцнення процесів електронного врядування, більшої прозорості, відповідальності та інклюзивності у відносинах 
між урядом і громадянами. Інституціональне управління дає можливість збільшити відповідність прийняття рішень, знизити рівень невизначеності, що є іманентною властивістю економічних процесів, забезпечити передумови переходу до моделі еволюційного послідовного розвитку.

Ключові слова: інститут, інституціональна трансформація, інституціональна реформа, модель економіки, правова держава, громадянське суспільство, управлінська система, інституціональне управління.

Существующая в Украине экономическая модель по своим базовым свойствам не нуждается в инновациях, не предусматривает инвестиций в человеческий капитал. Сегодня крайне необходима перестройка экономической модели Украины, которая должна быть переориентирована по стимулированию и финансовой поддержки крупного фринансово-промышленного капитала на развитие конкуренции, оптимизацию регулятивных функций государства и его роли в национальном процессе воспроизведения, значительную активизацию малого и среднего бизнеса. Отсюда, в плане институциональных трансформаций стратегической задачей современного этапа реформирования национальной экономики является построение эффективной системы управления на всех уровнях, определение новых ролей различных уровней государственного управления, которое предполагает оптимальное сочетание децентрализации и координирующей, стимулирующей роли центра.

Ключевые слова: институт, институциональная трансформация, институциональная рефрорма, модель экономики, правовое государство, гражданское общество, управленческая система, институциональное управление.

Formulation of the problem. Systematic understanding of the processes of economic transformations (changes) involves the consideration of transformations as processes of dying off of elements and connections of the old system and formation of new ones. The transformations of the economic system of Ukraine in the period of independence, like all the former socialist countries, differ in scale and unprecedented, similar measures, but differ in the achieved results. If most Central and Eastern European reform-oriented member states have achieved significant results and gained membership, Ukraine is in serious need of radical reform more than a quarter of a century since the reform began. However, current conditions are different from the conditions under which post-Soviet reforms have taken place, which creates new challenges for the country. The experience of post-socialist countries, which have already become EU members and are developing quite successfully, confirms the important role in the formation of a functioning economy of institutional reforms and socially effective institutions. That is why the study of economic development from the standpoint of the institutional-evolutionary approach, the definition and consideration of institutional transformations, the justification of their factors in the conditions of the next industrial revolution is the basis for understanding the options and development of mechanisms and instruments of future socio-economic transformations.

Analysis of recent research and publications. In the economic system, institutional structure plays an important role and the smooth operation of its components depends on institutional support. In the specialized literature, there are signifi- cant achievements of domestic and foreign scholars on institutional issues, and this development is constantly increasing, because institutional changes (transformations) are crucial factors in the dynamics of modern economic systems. In recent years, such national scientists as $\mathrm{S}$. Hasanov, V. Geyets, A. Gritsenko, V. Lagutin, V. Lypov, and $\mathrm{S}$. Stepanenko have made significant creative work in research and solving the scientific problem of transformational transformations of the national economy in the format of institutional changes. However, some theoretical and practical provisions regarding the current institutional transformations of the national economy in the globalized world remain underdeveloped and scientific-debated.

The purpose of the article is to deepen the existing theoretical and methodological foundations of the institutional transformations of the national economy and to identify priority directions of reforming the institutional structure of the Ukrainian economy, taking into account contemporary challenges and risks.

Outline of the main research material. In Ukraine since independence has been formed and consolidated a model of economy based mainly on low-tech ways and which can be competitive in the foreign market exclusively at the expense of cheap labor. Such an economic model by its fundamental properties does not require innovation and does not involve investment in human capital [4].The structural imbalance of the economy adversely affects the potential for further economic growth. However, in Ukraine there was no clear distinction between the economic interests of private capital, the bureaucratic nature of the state and public interests. In the absence 
of time-tested political institutions, generally accepted ways of preserving political heredity, as well as rules on the distribution of powers and material goods among heterogeneous groups, the state has become an arena of struggle between elites, clans and oligarchs.

In order to avoid deepening the economic, social and financial crisis with potential serious consequences for the economy and well-being, Ukraine's economic model should be refocused on stimulating and financially supporting large financial and industrial capital to promote competition, optimize the regulatory functions of the state and its role in the national process of reproduction. significant revitalization of small and medium-sized businesses [5].

Rebuilding national development models is becoming a typical phenomenon in the modern world. The economic development model involves defining goals on the basis of development priorities, identifying means of achieving the goals, developing mechanisms for implementing measures, identifying resources and executors, as well as timing of results. The analysis of legal regulation of development, program documents, national scientific reports, analytical materials until 2014 shows that despite declaring the goals, priorities, measures that are important and important for the economic development of Ukraine, their results have never been achieved or achieved minor results [7].

Comparing the achievements of the post-socialist countries of Europe and Ukraine, it is possible to identify the problematic places that determine the priority of further institutional changes:

- goal setting and shifts in the value system. CEE countries, while reforming clearly defined the goals, criteria and directions of the reforms underway, observed the unity of views of the new political elite and the public on the core values underlying the complex reforms. Ukraine has proclaimed a multi-vector and constant fluctuations between the western and eastern development vectors, raising the question of differences of opinion between residents and representatives of the political elites of the West and the East of the country;

- building a political system on democratic pluralistic foundations, and the revolutionary changes that took place in the late 1980s - early 1990 s in the CEE countries, were legitimized by the democratic elections in these countries on a multi-party competitive basis. It was thanks to the democratic elections that took place immediately after the fall of the communist regimes that many opposition to the communist regime succeeded in occupying a niche in the political system. In Ukraine, at the beginning of the reforms, the names and distribution of political power - the Communist Party - changed more quickly, and the people and the content of their activities remained the same. Only after almost 15 years, qualitative changes took place, but due to the lack of consent, the democratic forces lost their benefits;

- "path depends" conditions. The CEE countries were less than dominated by Soviet power for a while, still living representatives of a generation that remembered life before the establishment of Soviet power. In Ukraine, the dependence on the previous trajectory of development is manifested to a greater extent, as a significant number of the population was destroyed during the period of collectivization, the famine of 1932-33, the postwar famine (1947-1948), and public opinion on the movements for independence of the 1920s and the period of the Second World War was distorted by Soviet historiography;

- decentralization. In most CEE countries, administrative reforms have been implemented, financial decentralization has been implemented, which has made it possible to provide public services to citizens and communities more effectively, using limited resources effectively. Ukraine has only embarked on the path of decentralization reforms, the first steps of financial decentralization have been made, the process of enlargement of territorial communities on the basis of their voluntary unification is underway, but much remains to be done on this path;

- external influence and development of the financial market. At the beginning of the transformation, CEE countries received considerable financial assistance from the Western countries, so by reducing the debt-to-GDP ratio of Poland from $83 \%$ in 1990 to $56 \%$ in 1993 , the debt did not deplete the economy; there was a significant inflow of foreign capital, especially into the financial sector, which made it possible to rapidly shape the financial market and its institutions. In Ukraine, financial aid that went through the budget was used inefficiently and significant funds were transferred to private accounts due to high corruption of officials;

- the relationship of power, person and society. The effective functioning of the rule of law and civil society institutions is of paramount importance for the formation, approval and self-realization of the individual in a democratic European community. In the last twenty-five years, in most CEE countries, some strategic policy documents have been adopted regulating relations between the state and civil society organizations. Civil society in the CEE countries plays a significant role in establishing stable models of social democracy. In Ukraine, only in recent years, there has been a creation of working relationships within 
the framework of cooperation under the scheme "power-citizen-civil society" and such interaction takes time and perseverance, thoughtfulness and mutual interest.

The sources of economic growth and, accordingly, the well-being of the citizens of these countries are, first and foremost, not the «hard» but the "soft" factors: high level of education of citizens, active innovative activity, orientation of producers on consumer demand, willingness to provide high quality services. Both the state and investors invest heavily in such fields as education, education, science, research and more. All of the above is a compelling argument for the competitiveness of countries through high levels of social institutions development and competent management combined with world-class education and economic development based on high technology and innovation.

Despite the overall improvement of the Ukraine's rating, according to the results of the calculation of the Global Competitiveness Index in recent years, indicators remain low. The characteristic of the Ukrainian economy is the predominance in the structure of production of goods with low added value, energy and resource costs, the practical absence of competition in the domestic market, its small capacity, monopolization and regulation. But the competition in the domestic market is low, so we can not expect competitiveness in the international markets. Continued use of the cost economic model, lack of incentives for innovative processes and dynamic development of new technological structures make the Ukrainian economy uncompetitive, make it impossible to dramatically increase the standard and quality of life of the population, provoke increased social tensions.

In the phase of structural crisis caused by the substitution of technological structures, it is extremely important to advance the development of key productions of the core of the new technological device, which will allow to receive intellectual rent on a global scale and finance its expanded reproduction. In these conditions, developing countries are open to the possibility of accelerated development on the crest of a new long wave of economic growth due to the rapid formation of technological assemblages of the nucleus of a new technological way.

According to the leading scientists, specialists, experts, Ukraine has opportunities to ensure the development of the domestic economy based on modern technologies. Ukraine is one of eight countries in the world that have the scientific and technical potential to create modern aerospace technology. It is one of the ten largest shipbuilding countries in the world. The share of employ- ees in high- and medium-tech industries is significant. Ukraine maintains high-tech competitive industries in instrument making, power equipment manufacturing and heavy machinery, and in non-ferrous metallurgy. The scientific and technical potential of Ukraine is also quite high [6].

Given the growing technological backwardness of the Ukrainian economy against the background of becoming a new technological entity in advanced countries, the time to choose an innovative path of development is limited in the coming years. It is relatively easy to ride a new wave of economic growth in the process of its birth, relying on scientific background in the key technologies of the new technological way. Once it reaches maturity, this will require enormous investment. If the possibilities of structural restructuring of the Ukrainian economy on the basis of a new technological structure are lost, then its evolution will follow the inertial scenario, limited to the raw material periphery of the world economy.

The practical implementation of this task requires considerable administrative effort and requires the co-evolution of institutional, financial and economic development. Of particular importance, respectively, is the problem of power and governance. A serious ideological blunder in the development of transition models was the lack of awareness of the fact that the transition from a planned economy to a market economy is not simply a transition from coercion to economic freedom. The transformation of the socialist economy into a market economy is a transition from one system of government to another, from one type of coercion to another. In his work on the analysis of transformational processes, M. Olson wrote: "We now need a theory that focuses on coercive power, as well as the benefits it brings, a theory that explains behavioral motives for coercive power, and the motivating motives behind it, who already owns it» [3].

In Ukraine, in many respects, the system of economic management can be described as "manual» management. First and foremost, it concerns the inconsistency, inheritance, the "scrappy" nature of reform. As a result, there is a lack of timely modernization of production, insufficient and untimely consideration of changing conditions of production, inefficient structure of the economy, low rates of development of high-tech production, low adaptability of the national economy to rapid mines of the external environment, excessive centralization of financial resources. In addition, the management system itself is characterized by a number of negative phenomena:

- unjustified centralization of power. For the most part, central authorities restrict the autonomy of territorial communities, but thereby reduce 
the interest of citizens in common ideas. Deprivation of capacity to solve issues of one's own life support leads to loss of motivation for interaction of citizens with the state;

- the struggle of financial-industrial groups and regional elites for power;

- merging power and business. Business and government are virtually one single environment designed to meet the demands of a certain range of individuals. This negates the implementation of the fundamental principles of good governance, such as the rule of law, pluralism, justice, participation, transparency, accountability, access, efficiency and effectiveness. [8];

- protection through state structures, including power, private interests of individuals, raiding;

- corruption, that is, making decisions based on personal criteria [1];

- "market of public positions». Appointment to positions not by professional criteria, but by affiliation, for certain preferences, including financial.

Despite the negative phenomena in Ukraine, there are opportunities that, if properly used, will ensure economic prosperity and well-being of the population. Ukraine has a favorable geographical location for the development of transit, one third of the world's black soil, highly developed aviation and shipbuilding, military-industrial complex, about three percent of the world's energy reserves to become energy independent, recreational, tourist and scientific potential. Ukraine may become completely self-sufficient, but it is not enough to have resources, it is necessary to ensure their efficient and rational use. For this, the basic prerequisite is to build an effective management system at all levels.

Management of the economy in the modern period is mainly regulatory in nature and is based mainly on the principles defined by the wellknown German scientist V. Oyken [2]: the principle of individual freedom: the economic order must conform to the ideals of freedom and human dignity; the principle of systematic economic policy, which should be oriented towards a hierarchy of political goals and aimed at their implementation, which will protect the country from unsystematic, "experimental" actions of the state; the principle of a strong state: the state should not interfere with economic processes, but only create the conditions for their smooth flow. It aims only at the general ordering of social relations in a specific sector of the economy, which is carried out in accordance with the requirements of the law by directly influencing the economic activities of economic relations - the establishment of common rules, regulations, standards of a particular activity, and is defined as institutional management.

Recent events in the socio-political and socio-economic life of Ukraine show that the revealed patterns of transformation processes confirm the largely resonant and deforming interplay of transformations of the economic, political, social and spiritual spheres of Ukrainian society. For the further stabilization and economic development of the country it is necessary to ensure complementarity of transformation processes of different spheres of social life.

Conclusions. Therefore, economic transformations in Ukraine should be focused on solving the most important task - it is a radical change in the system of economic management at both macro and micro levels, the definition of new roles of different administrative levels, which provides the optimal combination of autonomy of the regions, especially in the field of everyday issues in local (regional) development and the coordinating, stimulating role of the center (representing the interests of society, the country as a whole). Institutional management makes it possible to create the conditions under which it is actually impossible to make wrong and selfish decisions, to reduce the level of uncertainty inherent in economic processes, to provide the prerequisites for the transition to a model of evolutionary sequential development.

Further transformations of the national economy should be based on the principles of political and nation-wide unification, a common vision of the goals and directions of socio-economic development of the country; a strategic, rather than a momentary, vision of the long-term results of reform; comprehensive, rather than "scrappy" partial implementation of reforms. It should be borne in mind that one of the main priorities for national development is to find a model of universal civic identity that is optimal and acceptable to the absolute majority of Ukraine, which would organically combine civic and socio-cultural components, take into account socio-cultural, ethnocultural and linguistic specificities.

References:

1. Kleiner G. (2012) Upravlenie cherez ritualy. [Control through rituals]. Direct investments, no. 2(118), pp. 12-14.

2. Oyken V. (1996) Osnovy nacionalnoj ekonomiky. [Fundamentals of the national economy]. Moscow: Progress. (in Russian)

3. Olson M. (1995) Rassredotochenie vlasti i obshestvo v perehodnyj period. [Power dispersal and society in transition]. Economics and mathematical methods, vol. 31, issue. 4. pp. 53-81. 
4. Pochenchuk G.M. (2016) Instytucionalnyj rozvytok ekonomiky v umovah finansovoyi globalizaciyi. [Institutional development of economy in the conditions of financial globalization]. Kyiv: Center for educational literature. (in Ukrainian)

5. Soskin O.I. (2010) Model narodnogo kapitalizmu yak osnova konkurentospromozhnogo rozvytku ekonomiky. [The model of popular capitalism as a basis for competitive economic development]. Economist, no 2, pp. 22.

6. Stepyko M.T. (2011) Ukrayinska identychnist: fenomeny i zasady formuvannya. [Ukrainian identity: phenomena and foundations of formation]. Kyiv: NISR. (in Ukrainian)

7. Nikiforov P.O. (ed.) (2018) Suchasni tendenciyi instytucionalnyh transformacij finansovoyi systemy Ukrayiny. [Current tendencies of institutional transformations of the financial system of Ukraine]. Chernivtsi: Tekhnodruk. (in Ukrainian)

8. What is Good Govermance? United nations ESCAP. URL: http://www.unescap.org/sites/default/ fies/good-govermance.pdf (accessed 20 January 2020). 